\title{
Screening for Biological Activities of Spirogyra neglecta Water Extract
}

\section{Atchariya YOSBOONRUANG ${ }^{1}$, Acharaporn DUANGJAI ${ }^{2}$, Doungporn AMORMLERDPISON ${ }^{3}$ and Jarupa VIYOACH ${ }^{4, *}$}

\author{
${ }^{I}$ Division of Microbiology and Parasitology, School of Medical Sciences, University of Phayao, \\ Phayao 56000, Thailand \\ ${ }^{2}$ Division of Physiology, School of Medical Sciences, University of Phayao, Phayao 56000, Thailand \\ ${ }^{3}$ Faculty of Fisheries Technology and Aquatic Resources, Maejo University, Chiang Mai 50290, Thailand \\ ${ }^{4}$ Department of Pharmaceutical Technology, Faculty of Pharmaceutical Sciences and Center of \\ Excellence for Innovation in Chemistry, Naresuan University, Phitsanulok 65000, Thailand
}

('Corresponding author's e-mail: jarupaviyoch4@yahoo.com,jarupav@nu.ac.th)

Received: 14 November 2017, Revised: 19 June 2018, Accepted: 30 July 2018

\begin{abstract}
The freshwater green algae, S. neglecta, has been commonly used as a Northern Thai local food due to the fact that it is composed of several nutritional components. The aim of the present study was to investigate the phytochemical properties and biological activities of an S. neglecta water extract for application as a functional food or pharmaceutical ingredient. The phenolic and flavonoid contents of $S$. neglecta and its biological activities, including anti-oxidant, pancreatic cholesterol esterase, antiinflammatory, cytotoxic, and antibacterial activities, were investigated in vitro. The results showed that the $S$. neglecta extract contained $157.92 \mathrm{mg} \mathrm{GAE} / \mathrm{g}$ extract of phenolics and $10.10 \mathrm{mg} \mathrm{CE} / \mathrm{g}$ extract of flavonoids. The radical scavenging activity of the $S$. neglecta extract exhibited an $\mathrm{IC}_{50}$ of $7.46 \pm 1.17$ $\mu \mathrm{g} / \mathrm{mL}$ from DPPH assay and $224.20 \pm 1.06 \mu \mathrm{g} / \mathrm{mL}$ from ABTS assay. Meanwhile, trolox exhibited an $\mathrm{IC}_{50}$ of $7.03 \pm 1.08 \mu \mathrm{g} / \mathrm{mL}$ from DPPH assay and $5.24 \pm 1.10 \mu \mathrm{g} / \mathrm{mL}$ from ATBS assay. Interestingly, the $S$. neglecta extract at $10 \mathrm{mg} / \mathrm{mL}$ inhibited pancreatic cholesterol esterase activity by $60 \%$. Moreover, the release of TNF- $\alpha$ from macrophages was strongly reduced by incubation with the $S$. neglecta extract in a dose-dependent manner, and all of the study concentrations were non-toxic to primary fibroblast cells. In addition, the $S$. neglecta extract inhibited some gram-positive and -negative bacteria. In summary, $S$. neglecta extract could possibly be used as a potential functional food or pharmaceutical ingredient, for which further studies are required.
\end{abstract}

Keywords: Spirogyra, algae, anti-inflammation, antioxidant, pancreatic cholesterol esterase

\section{Introduction}

Natural compounds from plants are widely used in both direct and indirect applications, such as in the composition of Thai local foods, folk medicines, and cosmetics. One good source of the natural compounds is from algae, which is well known and consumed in Asian countries such as Thailand. There are several reports on the biological activities of various types of algae, including brown algae, blue-green algae, and seaweeds. They contain many bioactive compounds with antioxidant, anti-inflammatory, and antimicrobial activities [1-4]. Both of the biologically active and nutritional compounds of various algae have been illustrated [4]. However, as far as we know, the information on the biological activities of freshwater green algae extract, particularly the water extract, has still not been clarified.

S. neglecta, or Tao (Thai local name), is a filamentous green alga in freshwater found in the North of Thailand. It is a traditional cuisine of the Northern Thai people. S. neglecta consists of various nutritional components, including protein, fat, carbohydrate, fiber, sulfate, multivitamins, and minerals 
http://wjst.wu.ac.th

[5]. The pharmacological properties of $S$. neglecta water extract has been reported in rats. S. neglecta extract could inhibit the formation of gastric ulcers from physical and chemical stresses in rats [6] and display antihyperlipidemia and antihyperglycemia in type 2 diabetic rats [7]. In addition, S. neglecta extract exhibited antioxidant capacity in rat liver [8]. However, other biological activities, including antiinflammation, antibacterial, and pancreatic cholesterol esterase activities of $S$. neglecta water extract, have never been reported. The aim of the present study was to investigate the phytochemical and biological activities, including antioxidant, anti-inflammatory, antibacterial, cytotoxic, and pancreatic cholesterol esterase activities, of $S$. neglecta water extract. This report could potentially support the biological information claims of $S$. neglecta extract for applications in functional food or other pharmaceutical products.

\section{Materials and methods}

\section{Chemicals}

Dulbecco's Modified Eagle's Medium (DMEM), lipopolysaccharide (LPS), Folin-Ciocalteu's phenol reagent, 1,1-diphenyl-2-picrylhydrazyl (DPPH), $\mathrm{AlCl}_{3}$ solution, catechin, $p$-nitrophenyl butyrate ( $p$-NPB), taurocholic acid sodium, porcine pancreatic cholesterol esterase, 2,2'-azinobis 3ethylbenzothiazoline-6-sulfonic acid (ABTS), and trypsin-EDTA were purchased from Sigma-Aldrich Co. (St. Louis, Missouri, U.S.A.). Fetal bovine serum (FBS) and penicillin/streptomycin were purchased from Gibco ${ }^{\mathrm{TM}}$ (Thermo Fisher Scientific, Waltham, Massachusetts, USA). Sodium 3-[1(phenylaminocarbonyl)-3,4-tetrazolium]-bis (4-methoxy-6-nitro) benzene sulfonicacidhydrate (XTT) was purchased from Roche Diagnostics (Hoffmann-La Roche, Basel, Switzerland). Gentamicin was purchased from Oxoid (Basingstoke, UK), and tryptic soy broth and agar (TSB and TSA) were purchased from Difco Laboratories, Inc. (New Jersey, USA).

\section{Preparation of $\boldsymbol{S}$. neglecta extract}

Fresh $S$. neglecta was collected from Na Kuha village, Saun Kuen subdistrict, Muang District, Phrae Province, Thailand. It was rinsed and dried at $50{ }^{\circ} \mathrm{C}$ in an oven. After grinding the dried S. neglecta into fine powder, $50 \mathrm{~g}$ of the $S$. neglecta powder was suspended in $1 \mathrm{~L}$ of distilled water and boiled at $100{ }^{\circ} \mathrm{C}$ for $1 \mathrm{~h}$. The aqueous solution was then filtered through filter paper. The boiling and filtering processes were performed three times, and the pooled solution was concentrated by evaporation. Then, it was lyophilized into dried extract powder by freeze drying, and the obtained yield of the extract was $36.67 \%$. The $S$. neglecta extract was stored at $4{ }^{\circ} \mathrm{C}$ prior to the subsequent experiments.

\section{Total phenolic content}

The total phenolic content was determined by using the Folin-Ciocalteu method [9]. In brief, $S$. neglecta extract $(2 \mathrm{mg} / \mathrm{mL})$ was mixed with $2 \mu \mathrm{L}$ of Folin-Ciocalteu's reagent. Eighty microliters of $\mathrm{Na}_{2} \mathrm{CO}_{3}$ solution $(15 \mathrm{~g} / \mathrm{L})$ was added to the mixture. The mixed solution was incubated at room temperature for $30 \mathrm{~min}$ before the absorbance at $750 \mathrm{~nm}$ was measured using a spectrophotometer. Gallic acid was used as the standard for the estimation of phenolics. The total phenolic content was performed in triplicate and expressed as mg of gallic acid equivalents (GAE) per g of dry weight.

\section{Total flavonoid content}

Total flavonoid content was determined by using the aluminum chloride colorimetric of Chang et al. with a slight modification [10]. In brief, $S$. neglecta extract $(2 \mathrm{mg} / \mathrm{mL})$ was added into a mixture of $60 \mu \mathrm{L}$ of $95 \%$ ethanol, $10 \mu \mathrm{L}$ of $4 \% \mathrm{AlCl}_{3}$ solution, and $10 \mu \mathrm{L}$ of $0.4 \mathrm{M}$ potassium acetate $\left(\mathrm{CH}_{3} \mathrm{COOK}\right)$. The solution was incubated for $40 \mathrm{~min}$ at room temperature before measuring the absorbance at $415 \mathrm{~nm}$ using a spectrophotometer. The standard curve for total flavonoids was made using catechin standard solution. The estimation of the flavonoid compounds was carried out in triplicate. The total flavonoids in the $S$. neglecta extract were expressed in terms of catechin equivalents per $g$ of dry weight. 
http://wjst.wu.ac.th

\section{Antioxidant activity by DPPH assay}

The free radical scavenging activity of $S$. neglecta extract was assessed according to the method described earlier with a slight modification [11]. S. neglecta extract $(10 \mu \mathrm{L})$ at various concentrations was mixed with $190 \mu \mathrm{L}$ of $80 \mu \mathrm{M}$ DPPH in methanol. All concentrations were prepared in triplicate. The reaction mixture was shaken well and incubated in the dark for $30 \mathrm{~min}$ at room temperature. Then, the absorbance was measured at $517 \mathrm{~nm}$. The antioxidant capacity of $S$. neglecta extract was expressed as $\mathrm{IC}_{50}$.

\section{Antioxidant activity by ABTS assay}

The scavenging activity of ABTS was measured as described previously [12]. Stock solution of ABTS and potassium persulfate was prepared. The mixture solution was kept in the dark at room temperature for $12 \mathrm{~h}$ to allow completion of radical generation. ABTS reagent was mixed with the extract or trolox, and the absorbance was taken at $734 \mathrm{~nm}$ after $6 \mathrm{~min}$ of incubation $(\mathrm{n}=3)$. The percentage of inhibition was calculated as: inhibition $\%=(1-$ absorbance at $734 \mathrm{~nm}$ of the extract or positive control/ absorbance at $734 \mathrm{~nm}$ of the control) $\times 100 \%$. The antioxidant capacity of $S$. neglecta extract was expressed as $\mathrm{IC}_{50}$.

\section{Determination of pancreatic cholesterol esterase activity}

Pancreatic cholesterol esterase activity was evaluated using $p$-nitrophenyl butyrate ( $p$-NPB) $[13,14]$. Taurocholic acid and $p$-NPB were prepared in absolute methanol. $S$. neglecta extract was mixed with taurocholic acid $(5.16 \mathrm{mM}), p$-NPB $(0.2 \mathrm{mM})$ and $100 \mathrm{mM}$ sodium chloride. Then, porcine pancreatic cholesterol esterase $(1 \mathrm{mg} / \mathrm{mL})$ was added to start the reaction. The absorbance at $405 \mathrm{~nm}$ was determined after incubation for $5 \mathrm{~min}$ at $25^{\circ} \mathrm{C}$. The experiment was performed in triplicate.

\section{Determination of anti-inflammatory activity}

In this study, tumor necrosis factor (TNF)- $\alpha$ was used as a marker of the inflammation produced from macrophages activated by LPS. Briefly, RAW264.7 cells (ATCC ${ }^{\circledR}$, TIB- $^{\mathrm{TM}}{ }^{\mathrm{TM}}$, VA, USA) were cultured in DMEM containing $10 \%$ FBS and antibiotics; then, they were incubated at $37{ }^{\circ} \mathrm{C}$ in a humidified atmosphere of $5 \% \mathrm{CO}_{2}$ for $24 \mathrm{~h}$. The medium was replaced with serum-free DMEM containing various concentrations of $S$. neglecta extract. After $30 \mathrm{~min}$ of incubation, $1 \mu \mathrm{g} / \mathrm{mL}$ LPS was added to activate pro-inflammatory production from RAW264.7. The cell-free supernatant was collected and TNF- $\alpha$ production was determined using TNF- $\alpha$ enzyme-linked immunosorbent assay kit (eBioscience, CA, USA). Finally, cell viability was determined by XTT-colorimetric assay [15]. The experiment was performed in triplicate.

\section{Determination of cytotoxicity}

\section{Cell isolation and culture}

Primary skin fibroblasts were used to determine cell viability after incubation with $S$. neglecta extract. Fibroblasts were isolated from the dermal tissue from excess surgery skin. The protocols were approved by the Naresuan University Human Ethics committee. Abdominal skin from a female, aged 55, was aseptically cut into small pieces. Two or three pieces of the skin were placed in a culture flask and subsequently incubated at $37{ }^{\circ} \mathrm{C}$ with a $5 \% \mathrm{CO}_{2}$ humidified atmosphere for $1 \mathrm{~h}$. After that, DMEM supplemented with $10 \%$ FBS and $1 \%$ of a stock penicillin/streptomycin was added, and the flask was subsequently incubated for 3 weeks. After the fibroblasts migrated from the original site, they were detached with a trypsin-EDTA solution and then seeded in new culture flask at $1 \times 10^{4} \mathrm{cells} / \mathrm{cm}^{2}$. Fibroblasts at passage number 4 were used in this study.

\section{Determination of cell viability}

Cell viability was performed to evaluate whether $S$. neglecta extract is toxic to human fibroblast cells. Fibroblasts $\left(1 \times 10^{4} \mathrm{cell} / \mathrm{cm}^{2}\right)$ were cultured in DMEM containing $10 \% \mathrm{FBS}$ and antibiotics at $37{ }^{\circ} \mathrm{C}$ in a humidified atmosphere of $5 \% \mathrm{CO}_{2}$ for $24 \mathrm{~h}$. Then, the medium was replaced with fresh serum-free DMEM containing various concentrations of $S$. neglecta extract and incubated for $24 \mathrm{~h}$. XTT solution was 
http://wjst.wu.ac.th

added and incubated at $37{ }^{\circ} \mathrm{C}$ for $4 \mathrm{~h}$. The cell-free supernatant was collected to measure the enzymatic activity at the absorbance of $490 \mathrm{~nm}$ using a spectrophotometer (Model CeresUV900C, Bio-tek Instrument, Winooski, Vermont, USA). Results were expressed as the percentage of cell viability compared to cell viability on the culture flask (control). Cell morphology was also observed under a light microscope. The experiment was performed in triplicate.

\section{Determination of antibacterial activity}

The tested microorganisms in this study were Staphylococcus aureus ATCC 25923, Staphylococcus epidermidis ATCC 12228, Escherichia coli ATCC 25922, and Pseudomonas aeruginosa ATCC 27853. Inoculums were prepared by culturing the microorganisms in TSB at $37^{\circ} \mathrm{C}$ for $18 \mathrm{~h}$. Inoculums were swabbed on TSA plates $\left(1 \times 10^{7} \mathrm{CFU} / \mathrm{mL}\right)$. After agar punching into the diameter of $6 \mathrm{~mm}$ by a sterile cork borer, three replications of the $S$. neglecta extract at a concentration of $200 \mathrm{mg} / \mathrm{mL}$ was applied to each well of the inoculated plates. Tetracycline $(4 \mu \mathrm{g} / \mathrm{mL})$ and sterile distilled water were used as a positive and negative control, respectively. All plates were incubated at $37{ }^{\circ} \mathrm{C}$ for $18-24 \mathrm{~h}$, and the diameter of the inhibition zone was measured in millimeters. A minimum inhibitory concentration (MIC) and a minimum bactericidal concentration $(\mathrm{MBC})$ of the extract were determined by broth dilution method.

\section{Statistical analysis}

The results were presented as mean \pm SD. Analysis of variance (ANOVA) was used for comparing the means using R i386 3.3.2. Significant differences were verified by Tukey's multiple range test at $p$ values $<0.001$.

\section{Results and discussion}

\section{Phenolic and flavonoid contents}

The total phenolic content of $S$. neglecta extract was analyzed using Folin-Ciocalteu's reagent and expressed as gallic acid equivalence (GAE) $\mathrm{mg} / \mathrm{g}$ extract. The total flavonoid concentrations were detected using aluminum chloride and represented as catechin equivalents $(\mathrm{CE}) \mathrm{mg} / \mathrm{g}$ extract. The results of the total phenolic and flavonoid contents are described in Table 1. The phenolic content in the $S$. neglecta extract was 157.92 Gallic acid equivalence (GAE) $\mathrm{mg} / \mathrm{g}$ extract. The concentrations of flavonoids showed 10.10 catechin equivalence (CE) $\mathrm{mg} / \mathrm{g}$ extract. These results indicated that the phenolic and flavonoid compounds of the $S$. neglecta extract still remained, although the $S$. neglecta was boiled at $100{ }^{\circ} \mathrm{C}$. Furthermore, a previous study reported that $S$. neglecta is composed of various nutritional components including protein, fat, carbohydrate, fiber, sulfate, multivitamins, and minerals $[5]$.

\section{Antioxidant activity}

The antioxidant activity was determined using DPPH assay and expressed as a percentage of inhibition. Trolox was used as a positive control. The $S$. neglecta extract showed DPPH radical scavenging activity with an $\mathrm{IC}_{50}$ of $7.46 \pm 1.17 \mu \mathrm{g} / \mathrm{mL}$, while trolox exhibited an $\mathrm{IC}_{50}$ of $7.03 \pm 1.08 \mu \mathrm{g} / \mathrm{mL}$. As presented in Table 1, the $\mathrm{IC}_{50}$ of the $S$. neglecta extract and trolox were $224.20 \pm 1.06 \mu \mathrm{g} / \mathrm{mL}$ and $5.24 \pm 1.10 \mu \mathrm{g} / \mathrm{mL}$, respectively. It can be suggested that $S$. neglecta extract was an effective antioxidant by radical scavenging activity. This study demonstrated that $S$. neglecta extract contains phenolics and flavonoids, similar to another study [8]. Accordingly, S. neglecta exhibiting high antioxidant capacity might be due to the components of $S$. neglecta extract including Gallic acid, eriodictyol, isoquercetin, kaempferol, quercetin, hydroquinin, rutin, catechin, and tannic acid [16]. In addition, Thumvijit et al. reported that the administration of hot water extract of $S$. neglecta presented antioxidant properties in rats by protecting tissue damage due to reactive oxygen species [17]. 
http://wjst.wu.ac.th

Table 1 The total phenolic, flavonoid contents and antioxidant activity of Spirogyra neglecta

\begin{tabular}{lccccc}
\hline & $\begin{array}{c}\text { Phenolic contents } \\
\text { (Gallic acid equivalence } \\
\text { (GAE) mg/g extract) }\end{array}$ & $\begin{array}{c}\text { Flavonoid contents } \\
\text { (Catechin equivalence } \\
\text { (CE) mg/g extract) }\end{array}$ & \multicolumn{2}{c}{$\begin{array}{c}\text { Antioxidant activity } \\
\text { IC }_{\mathbf{5 0}}(\boldsymbol{\mu} \text { g/mL) }\end{array}$} \\
\cline { 4 - 6 } Spirogyra neglecta & $157.92 \pm 0.33$ & $10.10 \pm 2.90$ & $7.46 \pm 1.17$ & $224.20 \pm 1.06$ \\
Trolox & - & - & $7.03 \pm 1.08$ & $5.24 \pm 1.10$ \\
\hline
\end{tabular}

\section{Pancreatic cholesterol esterase activity}

The $S$. neglecta extract played a role as an effective pancreatic cholesterol esterase inhibitor in a dose-dependent manner (Figure 1). The $S$. neglecta extract at $10 \mathrm{mg} / \mathrm{mL}$ markedly revealed the inhibition of pancreatic cholesterol esterase activity by $60 \%$. Several studies suggested that the pancreatic cholesterol esterase plays a role in the hydrolysis of cholesterol ester to cholesterol and free fatty acids. The unesterified cholesterol is easily absorbed in the intestine [18]. Inhibition of pancreatic cholesterol esterase enzyme might lead to a reduction of cholesterol absorption. It has been reported that cholesterol absorption was decreased in cholesterol esterase gene-knockout mice [19]. Our study showed the potential of $S$. neglecta extract as an anti-hyperlipidemic agent by the inhibitory effect against pancreatic cholesterol esterase. Ngamukote et al. revealed that three major polyphenols (gallic acid, catechin, and epicatechin) present in grape seeds have cholesterol-lowering activity by inhibiting pancreatic cholesterol esterase [13]. The methanol extract of the Camellia sinensis leaves containing flavonoids, phenolics, and terpenoids showed the ability to inhibit the pancreatic cholesterol esterase enzyme [20]. Karmar et al. suggested that plant-based polyphenols exhibited a potent inhibition of cholesterol esterase [20]. Therefore, it is possible that the inhibitory effect of $S$. neglecta on pancreatic cholesterol esterase is due to the presence of flavonoids and phenolic compounds in the extract.

\section{Anti-inflammatory activity}

To investigate the effect of $S$. neglecta extract on the production of pro-inflammatory cytokine, TNF- $\alpha$, Raw 264.7 macrophage cells were treated with/without the $S$. neglecta extract at various concentrations. The result showed that the $S$. neglecta extract significantly inhibited the release of TNF- $\alpha$ by macrophages (Figure 2). The percentage of TNF- $\alpha$ release from macrophages treated with the $S$. neglecta extract at various concentrations of $3.125-100 \mathrm{mg} / \mathrm{mL}$ was reduced to $46.16-7.67 \pm 1.8 \%$ (Figure 2). In addition, the results of morphology and cell viability indicated that the $S$. neglecta extract at the concentrations of $3.125-100 \mathrm{mg} / \mathrm{mL}$ was non-toxic to Raw 264.7 macrophage cells (data not shown). These findings exhibited the anti-inflammatory activity of $S$. neglecta extract without toxicity. It has been reported that many cytokines, such as TNF- $\alpha$, interleukin (IL) -6 , and IL-1 $\beta$, are produced by inflammatory tissues [21]. Heo et al. suggested that the major cytokine produced from macrophages is TNF- $\alpha$. It can stimulate the production of other cytokines, such as IL-6, IL-1 $\beta$, prostaglandin $\mathrm{E}_{2}\left(\mathrm{PGE}_{2}\right)$, and collagenase, which leads to septic shock, inflammation, and cytotoxicity [21]. Therefore, TNF- $\alpha$ is more important in playing a role in inflammation. The prevention of inflammation, according to the inhibition of cytokine production, particularly TNF- $\alpha$, is a key mechanism. Our result indicated that the $S$. neglecta extract strongly inhibited TNF- $\alpha$ production in RAW 264.7 macrophages stimulated by LPS, which indicated that $S$. neglecta extract has potential to be an inflammation inhibitor. It has been reported that several natural extract compounds can reduce or inhibit inflammatory cytokine production $[1,3,4,22,23]$. The effects of the anti-inflammatory activity of these antioxidant compounds are associated with their antioxidant activities. In this study, the active compounds that exhibited anti-inflammatory activity may be associated with phenolic and flavonoid contents in S. neglecta extract, which functions as an antioxidant. 


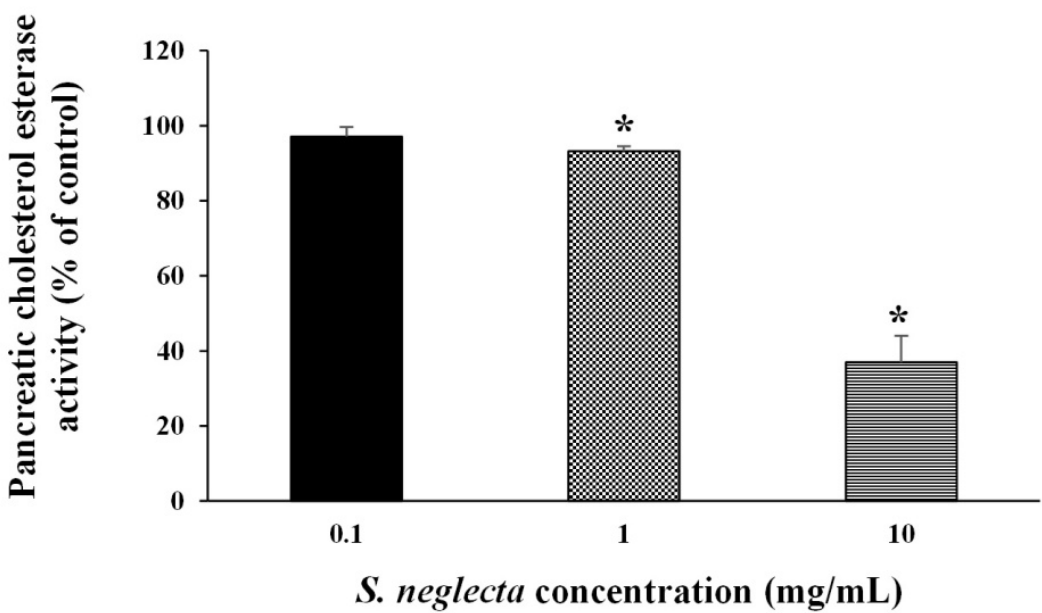

Figure 1 The effect of spirogyra neglecta on pancreatic cholesterol esterase activity. Results are expressed as mean \pm SEM., $\mathrm{n}=3 .{ }^{*} \mathrm{p}<0.001$

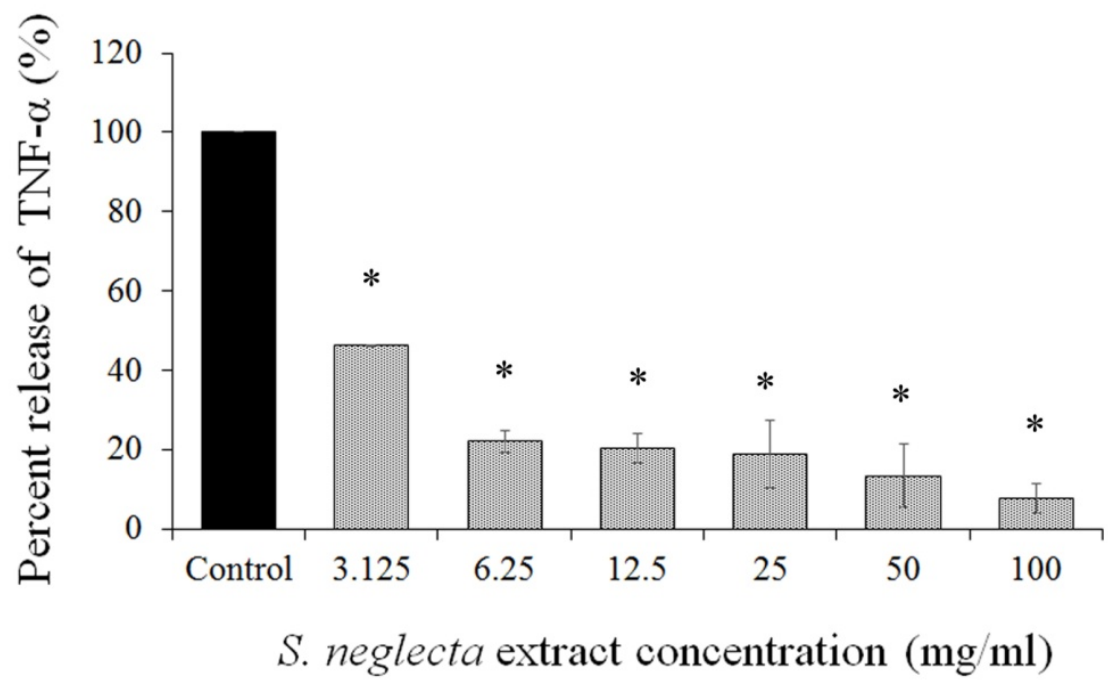

Figure 2 Percent TNF- $\alpha$ production in LPS-induced RAW 264.7 macrophages treated with various concentrations of $S$. neglecta extract. Control is LPS-induced RAW 264.7 macrophage without any treatment. The release of TNF- $\alpha$ was measured in culture media using ELISA technique. Data represented as mean $\pm \mathrm{SD}(\mathrm{n}=3) .{ }^{*} p<0.001$ 
http://wjst.wu.ac.th

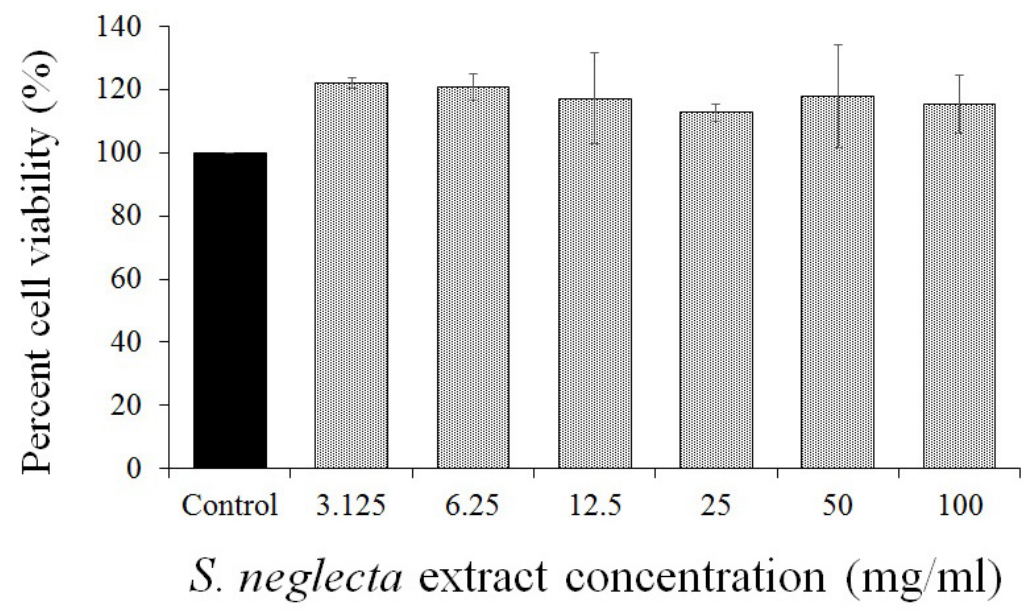

Figure 3 Percentage of fibroblast viability after exposure to various concentration of $S$. neglecta extract. Control is fibroblast unexposed to $S$. neglecta extract. Data represented as mean $\pm \mathrm{SD}(\mathrm{n}=3)$

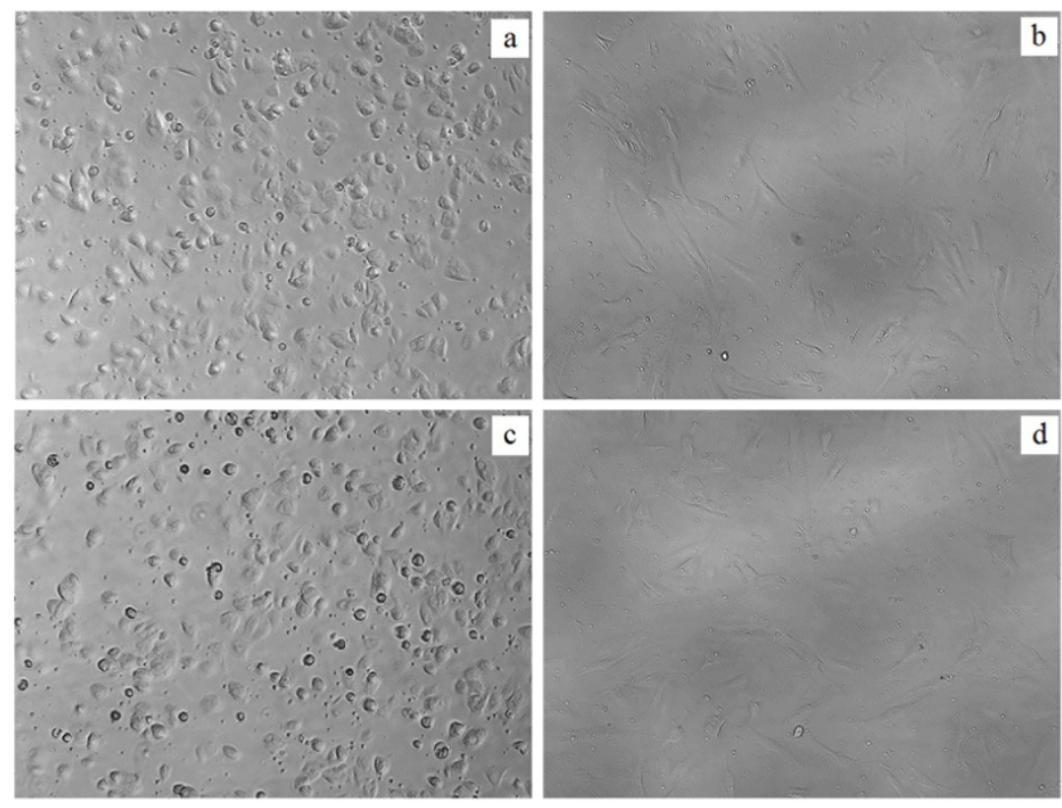

Figure 4 Primary human fibroblast morphology under 100X light microscope after incubation with $S$. neglecta extract for $0 \mathrm{~h}$ (a) and $24 \mathrm{~h}$ (b), and fibroblast incubation without $S$. neglecta extract at $0 \mathrm{~h}$ (c) and $24 \mathrm{~h}(\mathrm{~d})$

\section{Cytotoxicity investigation}

Cytotoxicity test was performed to determine the toxicity of $S$. neglecta extract at various concentrations on primary human fibroblasts. Cell viability after $24 \mathrm{~h}$ exposure to the $S$. neglecta extract was evaluated by measuring the viable cell metabolite using XTT assay. The results showed that, after incubation with the $S$. neglecta extract at concentrations of $100,50,25,12.5$, and $6.25 \mathrm{mg} / \mathrm{mL}$, the percentages of cell viability were 115.53, 117.80, 112.72, 117.14, and $120.75 \%$, respectively (Figure 3). 
http://wjst.wu.ac.th

The growth of cells unexposed to the $S$. neglecta extract was used as a control (adjusted as $100 \%$ ). It was indicated that cell viability after growing with the $S$. neglecta extract was not different from that without the $S$. neglecta extract. In addition, the fibroblast morphology under a light microscope (Figure 4) revealed a typical morphology of fibroblast after being treated with $100 \mathrm{mg} / \mathrm{mL}$ of the $S$. neglecta extract compared with the fibroblast growth on a plastic plate. They displayed a spindle-shaped phenotype similar to the control. According to a previous report, the extract from brown algae Sargassum vulgare was not toxic to erythrocytes and also promoted proliferation of macrophage cells [3]. On the other hand, Kazlowska et al. suggested that algae extract was slightly toxic toward RAW264.7 macrophage [1]. In the present study, after the human fibroblasts were treated with various concentrations of the $S$. neglecta extract, their morphology and viability were not different from those of the control (untreated by $S$. neglecta extract). It was indicated that $S$. neglecta extract was not toxic to human fibroblasts.

\section{Investigation of antibacterial activity}

The results of antibacterial activity using the agar well diffusion method are presented in Table 2. The $S$. neglecta extract was active against the tested microorganisms. The inhibition zones of the $S$. neglecta extract against $S$. aureus, $S$. epidermidis, and $P$. aeruginosa were shown as $28.33 \pm 0.58,26 \pm 0$, and $8.67 \pm 1.15 \mathrm{~mm}$, respectively. Meanwhile, E. coli was not inhibited by the $S$. neglecta extract at a concentration of $200 \mathrm{mg} / \mathrm{mL}$. Broth dilution technique could not produce the MIC or MBC due to the interference of an extract turbidity. However, the agar inside the inhibition zone of the positive result was punched and cultured on fresh TSA to determine the bactericidal activity of the extract. The result showed that the $S$. neglecta extract displayed bacteriostatic activity. Previously, the antibacterial activity of marine algae extract toward Vibrio strains [24] E. coli, P. aeruginosa, S. aureus, Enterococcus faecalis, etc. has been reported [25]. They suggested that the antibacterial effect was observed on the marine algae extract from various solvents, but was not observed on the water extract. In the present study, we found that the $S$. neglecta water extract exhibited activity against $S$. aureus, $S$. epidermidis, and $P$. aeruginosa, which may be related to the phenolic and flavonoid contents of $S$. neglecta extract. Moreover, a previous study on $S$. neglecta water extract [16] exhibited various effective compounds, including isoquercetin, hydroquinin, rutin, catechin, and tannic acid, which may be effective against various bacterial strains. Our results suggested that, after processing $S$. neglecta extract as a food additive or other pharmaceutical product, it can possibly prevent microorganism contamination.

Table 2 Inhibitory effect of $S$. neglecta extract against microorganisms

\begin{tabular}{lcc}
\hline \multirow{2}{*}{ Microorganisms } & \multicolumn{2}{c}{ Inhibition zone (mm) } \\
\cline { 2 - 3 } & $\begin{array}{c}\boldsymbol{S .} \text { neglecta } \text { extract } \\
(\mathbf{2 0 0} \mathbf{~} \mathbf{~ g} / \mathbf{m L})\end{array}$ & $\begin{array}{c}\text { Positive control } \\
\text { (Tetracycline) }\end{array}$ \\
\hline Staphylococcus aureus & $28.33 \pm 0.58$ & 40 \\
Staphylococcus epidermidis & $26 \pm 0$ & 40 \\
Escherichia coli & 0 & 35 \\
Pseudomonas aeruginosa & $8.67 \pm 1.15$ & 28 \\
\hline
\end{tabular}

\section{Conclusions}

The findings suggest that $S$. neglecta contains flavonoids and phenolic compounds, which might cause anti-hyperlipidemic properties by inhibiting pancreatic cholesterol esterase activity. Moreover, at the studied concentrations, $S$. neglecta extract exhibited an anti-inflammatory activity, and also inhibited some gram-positive and gram-negative bacteria. Our results indicate that $S$. neglecta has potential to be developed into an anti-hyperlipidemic agent, functional food, or other pharmaceutical product; however, additional studies, especially preclinical and clinical studies, are required. 
http://wjst.wu.ac.th

\section{Acknowledgements}

This study was supported by a grant from University of Phayao (Grant No.RD59053). We also thank the School of Medical Sciences, University of Phayao, for research facility support.

\section{References}

[1] K Kazlowska, T Hsu, CC Hou, WC Yang and GJ Tsai. Anti-inflammatory properties of phenolic compouds and crude extract from Porphyra dentate. J. Ethnopharmacol. 2010; 128, 123-30.

[2] R Pangestuti and Se-K Kim. Biological activities and health benefit effects of natural pigments derived from marine algae. J. Funct. Foods. 2011; 3, 255-66.

[3] CMPG Dore, MG das C Faustino Alves, LSEP Will, TG Costa, DA Sabry, LARS Rêgo, CM Accardo, HAO Rocha, LGA Filgueira and EL Leite. A sulfated polysaccharide, fucans, isolated from brown algae Sargassum vulgare with anticoagulant, antithrombotic, antioxidant and antiinflammatory effects. Carbohydr. Polym. 2013; 91, 467-75.

[4] IPS Fernando, JW Nah and YJ Jeon. Potential anti-inflammatory natural products from marine algae. Environ. Toxicol. Pharmacol. 2016; 48, 22-30.

[5] Y Peerapornpisal. Edible freshwater macroalgae in Northern Thailand. Fish. Sci. J. 2007; 1, 178-88.

[6] D Amornlerdpison, K Duangjun, D Kanjanapothi, $\mathrm{T}$ Taesotikul and Y Peerapornpisal. Gastroprotective activity of Spirogyra neglecta (Hassall) Kützing. KKU Sci. J. 2012; 40, 236-41.

[7] N Lailerd, A Pongchaidecha, D Amornlerdpison and Y Peerapornpisal. Beneficial effects of Spirogyra neclecta extract on glycemic and lipidemic status in streptozotocin-induced diabetic rats fed a diet enriched in fat. Ann. Nutr. Metab. 2009; 55, 709.

[8] T Thumvijit, W Thuschana, D Amornlerdpison, $\mathrm{Y}$ Peerapornpisal and R Wongpoomchai. Evaluation of hepatic antioxidant capacities of Spirogyra neglecta (Hassall) Kützing in rats. Interdiscip. Toxicol. 2013; 6, 152-6.

[9] MP Kahkonen, AI Hopia, HJ Vuorela, JP Rauha, K Pihlaja, TS Kujala and M Heinonen. Antioxidant activity of plant extracts containing phenolic compounds. J. Agric. Food. Chem. 1999; 47, 3954-62.

[10] CC Chang, MH Yang, HM Wen and JC Chern. Estimation of total flavonoid content in propolis by two complementary colorimetric methods. J. Food. Drug. Anal. 2002; 10, 178-82.

[11] MS BLOIS. Antioxidant Determinations by the use of a stable free radical. Nature 1958; 181, 1199200.

[12] R Re, N Pellegrini, A Proteggente, A Pannala, M Yang and C Rice-Evans. Antioxidant activity applying an improved ABTS radical cation decolorization assay. Free. Radic. Biol. Med. 1999; 26, 1231-7.

[13] S Ngamukote, K Makynen, T Thilawech and S Adisakwattana. Cholesterol-lowering activity of the major polyphenols in grape seed. Molecules 2011; 16, 5054-61.

[14] M Pietsch and M Gütschow. Synthesis of tricyclic 1, 3-oxazin-4-ones and kinetic analysis of cholesterol esterase and acetylcholinesterase inhibition. J. Med. Chem. 2005; 48, 8270-88.

[15] M Phetdee, A Polnok and J Viyoch. Development of chitosan-coated liposomes for sustained delivery of tamarind fruit pulp's extract to the skin Int. J. Cosmet. Sci. 2008; 30, 285-95.

[16] A Duangjai, N Limpeanchob, K Trisat and D Amornlerdpison. Spirogyra neglecta inhibits the absorption and synthesis of cholesterol in vitro. Integr. Med. Res. 2016; 5, 301-8.

[17] T Thumvijit, W Inboot, Y Peerapornpisal, D Amornlerdpison and R Wongpoomchai. The antimutagenic and antioxidant properties of Spirogyra neglecta (Hassall) Ktzing. J. Med. Plants. Res. 2013; 7, 2494-500.

[18] AP Kumar, A Sivashanmugam, M Umamaheswari, V Subhadradevi and P Jagannath. Cholesterol esterase enzyme inhibitory and antioxidant activities of leaves of Camellia sinensis (L.) Kuntze. using in vitro models. Int. J. Pharm. Sci. Res. 2011; 2, 2675-80.

[19] PN Howles, CP Carter and DY Hui. Dietary free and esterified cholesterol absorption in cholesterol esterase (bile salt-stimulated lipase) gene-targeted mice. J. Biol. Chem. 1996; 271, 7196-202. 
http://wjst.wu.ac.th

[20] TS Kumar, M Aishwarya, K Archana, S Divya, SS Lakshmi. Impact of polyphenols on cholesterol esterase inhibition: A mini review. Int. J. Res. Eng. Tech. 2016; 3, 1058-62.

[21] SJ Heo, WJ Yoon, KN Kim, GN Ahn, SM Kang, DH Kang, A Affan, C Oh, WK Jung and YJ Jeon. Evaluation of anti-inflammatory effect of fucoxanthin isolated from brown algae in lipopolysaccharide-stimulated RAW 264.7 macrophages. Food. Chem. Toxicol. 2010; 48, 2045-51.

[22] E Karimi, E Oskoueian, R Hendra, A Oskoueian and HZ Jaafar. Phenolic compounds characterization and biological activities of Citrus aurantium bloom. Molecules 2012; 17, 1203-18.

[23] T Yu, J Lee, YG Lee, SE Byeon, MH Kim. EH Sohn, YJ Lee, SG Lee and JY Cho. In vitro and in vivo anti-inflammatory effects of ethanol extract from Acer tegmentosum. J. Ethnopharmacol. $2010 ; 128,139-47$.

[24] G Genovese, C Faggio, C Gugliandolo, A Torre, A Spanò, M Morabito and TL Maugeri. In vitro evaluation of antibacterial activity of Asparagopsis taxiformis from the Straits of Messina against pathogens relevant in aquaculture. Mar. Environ. Res. 2012; 73, 1-6.

[25] SSA Al-Saif, N Abdel-Raouf, HA El-Wazanani and IA Aref. Antibacterial substances from marine algae isolated from Jeddah coast of Red sea, Saudi Arabia. Saudi. J. Biol. Sci. 2014; 21, 57-64. 